\title{
Survey of Plant-Parasitic Nematodes in Kansas and Eastern Colorado Wheat Fields
}

T. C. Todd, Department of Plant Pathology, Kansas State University, Manhattan 66506; J. A. Appel and J. Vogel, Kansas Department of Agriculture, Topeka 66612; and N. A. Tisserat, Colorado State University, Ft. Collins 80523

3 June 2014. 11 August 2014.

\section{ABSTRACT}

Todd, T. C., Appel, J. A., Vogel, J., and Tisserat, N. A. 2014. Survey of plant-parasitic nematodes in Kansas and Eastern Colorado wheat fields. Plant Health Progress doi:10.1094/PHP-RS-14-0003

Observations on the prevalence and abundance of plant-parasitic nematodes were made from soil and root samples collected from 2,640 wheat fields in Kansas and Colorado during 2007-2010. Stunt nematodes (predominately Merlinius brevidens and Quinisulcius acutus), root-lesion nematodes (predominately Pratylenchus neglectus), and pin nematodes (Paratylenchus projectus) were the most commonly encountered taxa. Maximum soil population densities of 6,520 and 1,880 nematodes/100 $\mathrm{cm}^{3}$ soil were observed for pin and stunt nematodes, respectively, while a maximum root population density of 90,309 nematodes/g dry root was observed for root-lesion nematodes. Lower nematode densities were associated with wheat following corn, grain sorghum, or soybean for pin

\section{INTRODUCTION}

Kansas ranks first or second each year in U.S. wheat production, with 10 million metric tons (360 million bushels) produced on 3.2 million hectares (8 million acres) in 2010 (35). Colorado also is a major wheat-producing state, ranking fifth in U.S. wheat production in 2010, with 3 million metric tons (108 million bushels) produced on 1 million hectares ( 2.4 million acres) (1). The 2010 wheat crop was valued at $\$ 1.8$ billion and $\$ 600$ million for Kansas and Colorado, respectively. Hard winter wheat is the dominant class of wheat produced in both states, with production concentrated in eastern Colorado and the western twothirds of Kansas.

Wheat diseases in Kansas are surveyed annually and are estimated to cause an average loss of $12 \%$ (2). The Kansas Plant Disease Survey was formalized by the Kansas State Board of Agriculture in 1976 to complement existing annual crop reports and insect surveys. The annual wheat disease survey initially targeted fungal, bacterial, and viral diseases, but did not include plant-parasitic nematodes due to the difficulty in observing, sampling, and measuring soil-associated pathogens. Additionally, the economic impact of nematodes in winter wheat in the central Great Plains generally has gone unrecognized, despite a long history of observations of significant injury due to stunt (Merlinius brevidens) and root-lesion (Pratylenchus spp.) nematodes $(3,13,21,22)$. The evidence for economic damage in wheat from Pratylenchus spp. is particularly convincing, with nematicide applications for control of these nematodes in Oklahoma resulting in dollar value increases of $20 \%$ and $9 \%$ for

Corresponding author: Tim Todd. Email: nema@ksu.edu

doi:10.1094/PHP-RS-14-0003 (C) 2014 The American Phytopathological Society and stunt nematodes, and with wheat following fallow for root-lesion nematodes. Based on the results of this survey, $6 \%$ and $8 \%$ of wheat acreage in the central Great Plains are estimated to be at risk for significant $(>5 \%)$ yield loss due to stunt nematodes and root-lesion nematodes, respectively. The number of fields with high population densities of both stunt and root-lesion nematodes was negligible (1\%); therefore, the total wheat acreage with nematode populations above provisional economic thresholds is estimated to be $\sim 13 \%$. Damage relationships with greater accuracy, precision, and relevance are necessary to establish reliable yield loss estimates for this region.

forage and grain yields, respectively, across multiple locations and years (21). Nematicide control of $P$. thornei in eastern Colorado produced even greater yield increases of $28 \%$ (3). More recently, root-lesion nematodes have been demonstrated to be important limiting factors in the production of spring wheat in Australia and Mexico, and both spring and winter wheat in the Pacific Northwest United States (19,20,24,25,26,36).

In 2007, the United States Department of Agriculture's Cooperative Agricultural Pest Survey program placed the British root-knot nematode (Meloidogyne artiella), the Mediterranean cereal cyst nematode (Heterodera latipons), and another cereal cyst nematode, $H$. filipjevi, on its list of targeted primary pests for survey (29). This program provided an opportunity to conduct the first comprehensive survey of nematode parasites of wheat in the central Great Plains. A cooperative effort between Colorado State University and Kansas State University was initiated in 2007 to sample and census nematode populations in wheat fields across eastern Colorado and, beginning in 2008, a three-year survey of wheat fields in Kansas was conducted by the Kansas Department of Agriculture and Kansas State University.

\section{SAMPLING AND EXTRACTION METHODS}

Over the four-year period from 2007 to 2010, a total of 2,640 samples were collected from Kansas and eastern Colorado. A systematic sampling protocol was established prior to initiation of sample collection, with sampling stratified by county and by section within county (no more than one sample per section), subject to road access. Field selection for sampling was based on the criteria that the field was representative of wheat production in that county or immediate area and that field locations were separated by at least $1.6 \mathrm{~km}$ ( 6 to $9 \mathrm{~km}$ in most cases). Sample size was based on production hectares, with each sample representing approximately 2,000 ha on a per county basis. This 
sampling rate fell within guidelines proposed for detecting exotic pests such as $M$. artiella and $H$. latipons $(5,6)$. Samples were collected from a 0.4-ha-sized area near an entry point of each field. Collection began about six weeks after growth resumed in the spring each year and the wheat had reached at least the Feekes 5-6 (pseudostem erect to first node visible) growth stages (14). Soil temperatures at this six-week period were conducive for resumption of feeding and reproduction by overwintering nematode populations, thus improving the chances of detection and assessment of targeted species in soil and root samples. Sampling continued through April and May (June in northeastern Colorado) generally moving from southern counties to northern counties. Crop residue from the previous growing season was recorded at each location.

Soil samples consisted of 152.5 -cm-diameter cores equally spaced and collected within plant rows by probing directly into wheat root systems to a depth of 12 to $15 \mathrm{~cm}$. Root samples (from Kansas only) were collected by digging three sub-samples of 3 plants each and clipping the roots. Soil and root samples with stored in separate bags in a cooler and then shipped to the laboratory within 4 days of collection. GPS locations were taken at each entry point. Date, growth stage, and previous crop information was recorded for each sample.

The 2007 survey was conducted in northeastern Colorado and consisted of 535 samples collected from 9 counties. The 2008 survey was conducted in western Kansas counties, with 700 samples collected from 27 counties. Dry soils made collection at times difficult in some of the counties until late April rains arrived. In 2009, 729 samples were collected from 25 counties in central Kansas. Sampling conditions were initially dry, but an April blizzard that deposited over $68 \mathrm{~cm}$ of snow in some counties delayed wheat development and sampling. The 2010 survey was conducted over the eastern half of Kansas with 683 samples collected from 50 counties. Sampling did not begin until early April due to cool soil temperatures and slow wheat growth following winter dormancy. Three counties in eastern Kansas were not included in the survey, because acreage did not meet the criteria of having 2,000 ha of wheat production.

Nematodes were extracted from $100 \mathrm{~cm}^{3}$ sub-samples of soil using a standard centrifugal-flotation technique (11) and from 2.5 $\mathrm{g}$ fresh weight sub-samples of wheat roots incubated in aerated tap water for 1 week (9). Nematodes were identified to genus and enumerated using an Olympus SZX16 zoom stereomicroscope. Selected individual nematodes were identified to species using an Olympus BX50 compound microscope.
Nematode counts were analyzed using SAS Proc Univariate (SAS v. 9.1, SAS Institute Inc., Cary, NC). Covariance estimates for year, crop reporting district (2), county, and field were obtained using SAS Proc Mixed, with all variables treated as random effects. Population density means were compared for cropping history effects after counts were log-transformed to reduce heterogeneity of variances.

\section{NEMATODE PREVALENCE}

Stunt nematodes (Telotylenchidae) were the plant-parasitic taxa most frequently recovered during this survey, with a prevalence of $79 \%$ and $81 \%$ for Colorado and Kansas, respectively (Table 1). Merlinius brevidens and Quinisulcius acutus were the dominant species present, but several species of Tylenchorhynchus also were common. The mean population density for stunt nematodes in infested fields in Colorado and Kansas was 42 and 81 nematodes $/ 100 \mathrm{~cm}^{3}$ soil, respectively, with approximately $25 \%$ of all fields surveyed having population densities greater than the mean (Fig. 1A; data shown for Colorado and Kansas collectively). Prevalence and mean population densities of stunt nematodes were greater for this survey than those reported from a survey of cereal crops in the Pacific Northwest United States, where Smiley et al. (24) detected stunt nematodes in only $35 \%$ of fields sampled with a mean population density in infested fields of approximately 40 nematodes/100 g soil. Prevalence of stunt nematodes was similar to that for Tylenchorhynchus spp. (78\%) in southeastern Idaho (28) and M. brevidens (73\%) in northern Australia (31).

Root-lesion nematodes (Pratylenchus spp.) were recovered from $78 \%$ of Colorado soil samples and $77 \%$ of Kansas root samples (Table 1). Pratylenchus neglectus was the species present in most fields, with $P$. thornei present in approximately $1 \%$ of samples from both Colorado and Kansas (data not shown). Pratylenchus penetrans was common in eastern Kansas, but represented $<1 \%$ of all root-lesion nematode populations recovered during the survey (data not shown). Mean soil population densities of Pratylenchus spp. in infested fields were similar between the two states, averaging 48 to 49 nematodes/100 $\mathrm{cm}^{3}$ soil. Population densities exceeded the mean density in $20 \%$ and $14 \%$ of soil samples, and exceeded 200 nematodes $/ 100 \mathrm{~cm}^{3}$ soil in $4 \%$ and $2.5 \%$ of soil samples, from Colorado and Kansas, respectively (Fig. 1B; data shown for Colorado and Kansas collectively). Numbers of root-lesion nematodes per $\mathrm{g}$ dry root averaged 1,942 for infested fields in Kansas, with a maximum of 90,309 nematodes per $\mathrm{g}$ dry root recovered from Pratt County in

\begin{tabular}{|c|c|c|c|c|c|c|}
\hline \multirow[b]{4}{*}{ Nematode taxon } & \multicolumn{5}{|c|}{$\begin{array}{l}\text { TABLE } 1 \\
\text { Prevalence and population densities of nematode taxa recovered } \\
\text { during a survey of eastern Colorado and Kansas during 2007-2010. }\end{array}$} & \\
\hline & & & \multicolumn{4}{|c|}{ Nematodes $/ 100 \mathrm{~cm}^{3}$ soil or g root } \\
\hline & \multicolumn{2}{|c|}{ Prevalence (\%)* } & \multicolumn{2}{|c|}{ Mean* } & \multicolumn{2}{|c|}{ Maximum* } \\
\hline & co & KS & CO & KS & CO & KS \\
\hline Telotylenchidae & 78.7 & 81.0 & 42 & 81 & 316 & 1,880 \\
\hline Pratylenchus - root & N/A & 76.9 & N/A & 1,942 & N/A & 90,309 \\
\hline Paratylenchus & 12.1 & 27.6 & 159 & 180 & 1,180 & 6,520 \\
\hline Helicotylenchus & 2.6 & 7.5 & 24 & 53 & 104 & 1,220 \\
\hline Xiphinema & 2.6 & 4.4 & 6 & 11 & 16 & 220 \\
\hline Criconematidae & 0.4 & 0.4 & 20 & 17 & 36 & 40 \\
\hline Hemicycliophora & 0.0 & 0.7 & N/A & 201 & N/A & 760 \\
\hline
\end{tabular}

* $\mathrm{N}=535$ and 2,105 for Co and KS, respectively. Mean and maximum are for infested fields only. N/A indicates that data were not collected or that prevalence was zero. 

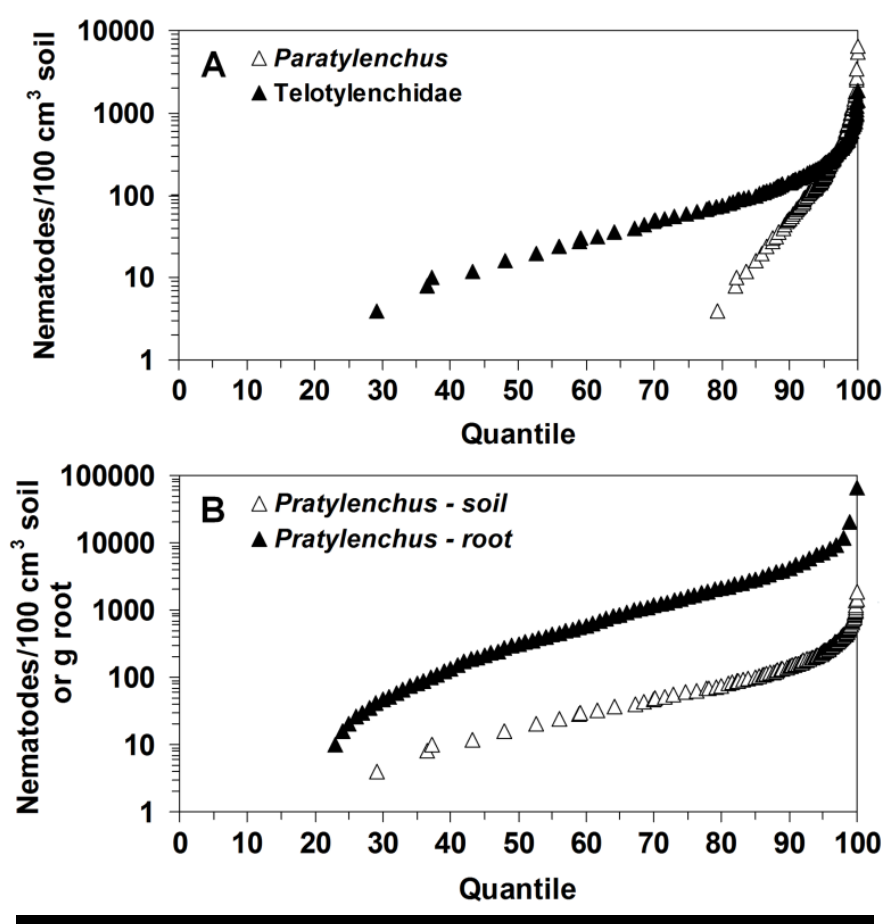

FIGURE 1

Fig. 1. Cumulative frequencies of (A) pin (Paratylenchus projectus) and stunt (Telotylenchidae) nematode population densities and (B) rootlesion (Pratylenchus spp.) nematode population densities in Colorado and Kansas during 2007-2010. Quantiles represent the proportion of samples (fields) with a population density less than that indicated by an individual symbol.

2009 (Table 1). Population densities exceeded the mean density in $20 \%$ of root samples and exceeded 5,000 nematodes/g dry root in $8 \%$ of root samples (Fig. 1B). These numbers are somewhat lower than those reported for the Pacific Northwest, where root-lesion nematodes were recovered from $95 \%$ of sampled fields, with root population densities exceeding 1,500 per g dry root in $41 \%$ to $46 \%$ of fields, and 5,000 per g dry root in $11 \%$ to $21 \%$ of fields (24). A survey of wheat and barley fields in southeastern Idaho revealed a similarly high prevalence $(96 \%)$ of root-lesion nematodes, mostly $P$. neglectus (28). In contrast, wheat fields in northern Australia were found to have a high prevalence $(67 \%)$ of $P$. thornei, but a relatively low prevalence (32\%) of $P$. neglectus (31)

Pin nematodes (Paratylenchus projectus) were recovered from $12 \%$ and $28 \%$ of Colorado and Kansas wheat fields, respectively, with a mean population density in infested fields of 159 to 180 nematodes $/ 100 \mathrm{~cm}^{3}$ soil (Table 1 ). Only $5 \%$ of samples contained population densities exceeding the mean density, but maximum soil population densities were greater for this nematode than for any other taxon (Table 1, Fig. 1A). Smiley et al. (24) detected pin nematodes in $10 \%$ of Pacific Northwest samples, with mean and maximum densities of 26 and 2,021 nematodes/100 g soil, respectively.

Spiral (Helicotylenchus spp.), dagger (Xiphinema spp.), ring (Criconematidae), sheath (Hemicycliophora spp.), and stubby root (Paratrichodorus spp.) nematodes were recovered from $<10 \%$ of Colorado and Kansas wheat fields (Table 1). Heterodera glycines was recovered from $2.5 \%$ of soil samples collected in eastern Kansas, where the nematode is widely established in soybean production fields. Other cyst nematodes, such as $H$. avenae and $H$. filipjevi, which are known to be present in the Pacific
Northwest (37), as well as the USDA-targeted exotics, the British root-knot nematode $M$. artiella and the Mediterranean cereal cyst nematode $H$. latipons, were not recovered during this survey.

In general, population densities of pin, stunt, and root-lesion nematodes were positively correlated ( $r=0.09$ to $0.37, P \leq 0.05$ ) across sample sites. Stunt nematode populations in soil and rootlesion nematode populations in wheat roots were negatively correlated $(r=-0.36, P<0.0001)$ at population densities above theoretical damage thresholds. Although circumstantial, this reasonably could be interpreted as evidence for interspecific competition in the presence of resource limitations (e.g., restricted root growth) resulting from nematode feeding injury.

\section{GEOGRAPHIC DISTRIBUTION}

No detectable patterns were observed for nematode prevalence across eastern Colorado or western through central Kansas, although maximum densities tended to be concentrated in southern central Kansas (Fig. 2). Both prevalences and densities of stunt, root-lesion, and pin nematodes declined, however, in eastern Kansas, likely a result of the notable gradients in soil texture, precipitation, and cropping systems that occur across the region. The effects of these gradients are confounded and difficult to partition. For example, soil textures are dominated by silt loams in xeric eastern Colorado and western Kansas, while silty clay loams are common in more mesic eastern Kansas. Population development of $P$. projectus is favored by silt loam soils compared to silty clay loam soils (8), and P. neglectus has been reported to be associated with loamy soils, while $P$. thornei is more prevalent in heavier soils $(12,18)$. These patterns in soil preferences are not always consistent, however. It is likely that reduced wheat cropping frequency in eastern Kansas also contributed to the nematode distributions observed during this survey.

Covariance estimates for the Kansas survey data indicate that variation among fields within county and year accounted for $84 \%$ to $94 \%$ of the total variation in nematode densities, while variation among Crop Reporting Districts (2) and years accounted for only $0 \%$ to $3 \%$ and $1.5 \%$ to $7 \%$, respectively, of the total variation in nematode densities (Table 2). Although survey samples were collected by geographic region across four years (including the Colorado data), it is clear that year effects were relatively insignificant, and that the results can be generalized for making inferences about the distribution of plant-parasitic nematodes and any associated yield loss for wheat in Kansas and eastern Colorado. While large-scale generalizations may be relatively consistent at the state or regional level, they are not very reliable at the field scale, emphasizing the necessity of regular monitoring of nematode populations in individual fields.

\section{CROP ROTATION EFFECTS}

The effect of previous crop on nematode population densities in wheat soil or roots is summarized in Table 3. Pin and stunt nematode population densities were reduced $68 \%$ and $31 \%$, respectively, when the wheat crop was preceded by corn, grain sorghum, or soybean. Root-lesion nematode population densities were not affected by previous crop, but were $38 \%$ and $12 \%$ lower in wheat soil and roots, respectively, when the wheat crop was preceded by a fallow period. Despite the results observed for pin and stunt nematodes, the relatively broad host ranges of the dominant nematode species recovered during this survey suggests that the prospect for using crop rotation to manage plant-parasitic nematodes in wheat production fields in Colorado and Kansas is limited. In particular, corn, grain sorghum, and/or soybean have been reported to be moderate to good hosts for $P$. projectus, 


\section{FIGURE 2}

Fig. 2. Geographic distribution of (A) stunt (Telotylenchidae), (B) pin (Paratylenchus projectus), and $(\mathbf{C})$ root-lesion (Pratylenchus spp.) nematode soil population densities in samples collected in Colorado and Kansas wheat fields during 2007-2010, and (D) root-lesion (Pratylenchus spp.) nematode root population densities in samples collected in Kansas during 2008-2010.

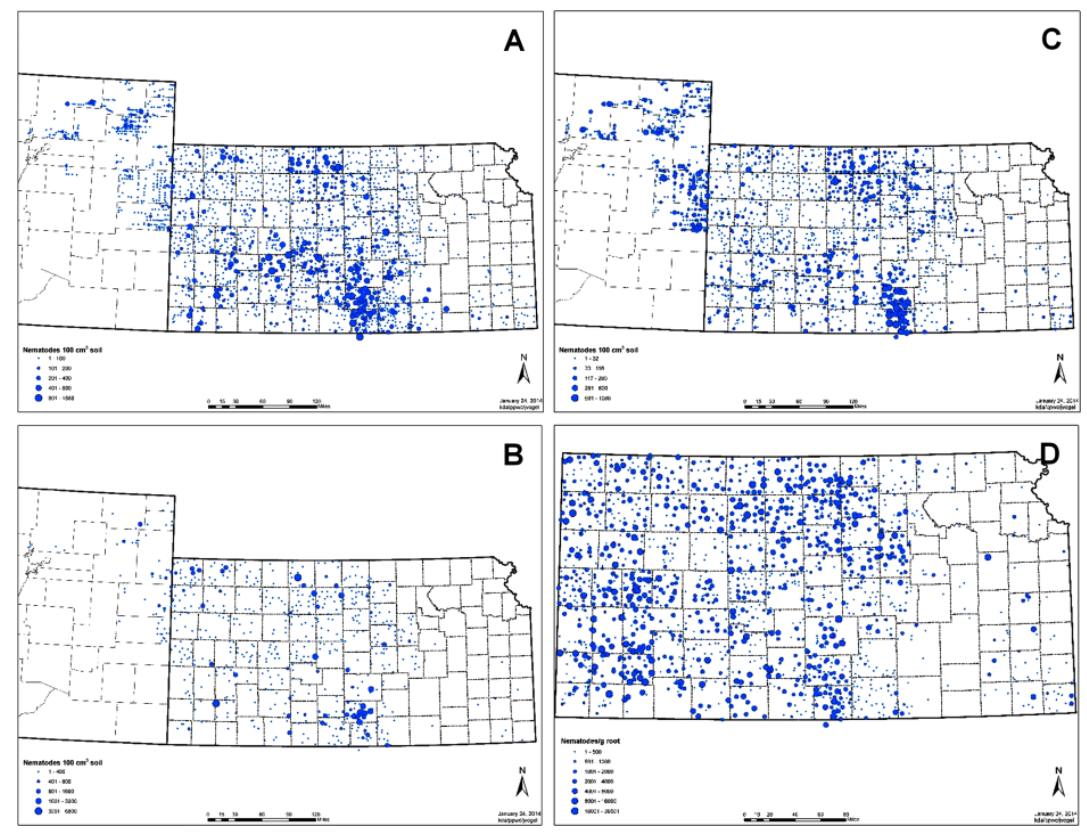

\begin{tabular}{|c|c|c|c|c|}
\hline \multirow[b]{3}{*}{ Variance component } & \multicolumn{4}{|c|}{$\begin{array}{l}\text { TABLE } 2 \\
\text { Variance component estimates for nematode population densities across years, } \\
\text { crop reporting districts (CRD), counties (Co.), and fields in Kansas during 2008-2010. }\end{array}$} \\
\hline & \multicolumn{3}{|c|}{ Nematodes $/ 100 \mathrm{~cm}^{3}$ soil } & \multirow{2}{*}{$\begin{array}{c}\text { Nematodes/g root } \\
\text { Pratylenchus }\end{array}$} \\
\hline & Paratylenchus & Telotylenchidae & Pratylenchus & \\
\hline Year & $\begin{array}{c}1,115 \pm 1,376 \\
(P=0.090)^{*}\end{array}$ & $\begin{array}{c}1,137 \pm 1,301 \\
(P=0.028)\end{array}$ & $\begin{array}{l}322 \pm 403 \\
(P=0.084)\end{array}$ & $\begin{array}{c}238,325 \pm 324,008 \\
\quad(P=0.082)\end{array}$ \\
\hline Co. (CRD Year) & $\begin{array}{l}4,280 \pm 977 \\
(P<0.0001)\end{array}$ & $\begin{array}{l}1,160 \pm 282 \\
(P<0.0001)\end{array}$ & $\begin{array}{c}607 \pm 126 \\
(P<0.0001)\end{array}$ & $\begin{array}{c}368,356 \pm 143,778(P= \\
0.047)\end{array}$ \\
\hline Field (Co. CRD Year) & $\begin{array}{c}68,929 \pm 2,157 \\
(P<0.0001)\end{array}$ & $\begin{array}{l}14,563 \pm 457 \\
(P<0.0001)\end{array}$ & $\begin{array}{l}5,840 \pm 183 \\
(P<0.0001)\end{array}$ & $\begin{array}{c}12,556,993 \pm 393,949 \\
(P<0.0001)\end{array}$ \\
\hline
\end{tabular}

* Probability for Ho: estimate $=0$ vs. Ha: estimate $>0$.

\begin{tabular}{|c|c|c|c|c|c|}
\hline \multicolumn{6}{|c|}{$\begin{array}{l}\text { TABLE } 3 \\
\text { Effect of previous crop on nematode population densities in wheat soil or roots in Kansas during 2008-2010. }\end{array}$} \\
\hline \multirow[b]{2}{*}{ Previous crop } & \multirow[b]{2}{*}{$\mathbf{N}$} & \multicolumn{3}{|c|}{ Nematodes $/ 100 \mathrm{~cm}^{3}$ soil } & \multirow{2}{*}{$\begin{array}{c}\text { Nematodes/g root } \\
\text { Pratylenchus }\end{array}$} \\
\hline & & Paratylenchus & Telotylenchidae & Pratylenchus & \\
\hline Wheat & 1,168 & $63 \mathrm{a}$ & $69 a$ & $34 \mathrm{a}$ & $1,470 \mathrm{a}$ \\
\hline Fallow & 371 & $51 \mathrm{ab}$ & $75 \mathrm{ab}$ & $21 \mathrm{~b}$ & $1,288 \mathrm{~b}$ \\
\hline Corn & 220 & $15 \mathrm{c}$ & $52 \mathrm{bc}$ & $34 \mathrm{a}$ & $1,504 \mathrm{ab}$ \\
\hline Grain sorghum & 208 & $11 \mathrm{bc}$ & $49 \mathrm{bc}$ & $14 a b$ & $1,442 \mathrm{ab}$ \\
\hline Soybean & 132 & $35 \mathrm{bc}$ & $41 \mathrm{c}$ & $31 \mathrm{ab}$ & $1,983 \mathrm{ab}$ \\
\hline
\end{tabular}

* Means within a column with the same letter are not different $(\mathrm{P} \leq 0.05)$ based on Bonferroni's method for controlling experiment-wise error rates.

$Q$. acutus, and $P$. neglectus $(4,7,8,16,17,34)$. It is unlikely, therefore, that these nematodes can be collectively managed with crop rotation, given the crops commonly used in rotations in this region.

The observation that lower root-lesion nematode population densities were associated with wheat following fallow is supported by similar evidence from the Pacific Northwest (24). Root-lesion nematodes can be distributed across much greater depths in the soil profile than that sampled during this survey $(23,32)$, suggesting that a more extensive sampling regime is necessary to confirm these results. It should be further noted that previous studies have documented anhydrobiosis in $P$. thornei and possibly $P$. neglectus, as well as in $M$. brevidens, potentially limiting any beneficial effects resulting from a fallow period for these species $(10,30,33)$.

\section{ECONOMIC IMPACT}

Strong evidence of economic damage to wheat due to nematode parasitism exists only for $M$. brevidens, $P$. neglectus, and $P$. thornei. Merlinius brevidens has been associated with stunting 
and yield reductions in wheat since the 1960s $(13,22)$, and pathogenicity has been confirmed in controlled-environment experiments (15). More recently, nematicide applications to spring wheat in soils infested with $M$. brevidens resulted in yield increases of $17 \%$ across three Pacific Northwest environments (27). Initial population densities as low as 10 nematodes/100 g soil were associated with yield reductions of 8 to $24 \%$ in that study. Using a more conservative threshold of 200 nematodes/100 $\mathrm{cm}^{3}$ soil for an expected yield loss greater than 5\% (13), $1 \%$ and $7 \%$ of fields in Colorado and Kansas, respectively, would be anticipated to be at risk for significant injury from stunt nematodes. This may be an overestimate, however, since many fields contained stunt nematodes other than M. brevidens, for which the evidence for yield suppression in wheat is much weaker or nonexistent.

Damage relationships for $P$. neglectus on winter wheat in the Pacific Northwest suggest that a $10 \%$ yield loss occurs at a root population density of 1,000 nematodes/g dry root during grain fill (24). For spring wheat, a $10 \%$ yield loss was predicted to occur at initial soil densities of 100 to 370 (mean $=200)$ nematodes $/ 100 \mathrm{~g}$ soil, depending on cultivar (26). If these relationships are applied to the Colorado/Kansas survey data, the estimated yield loss would be $2.4 \%$ and $1.9 \%$ for Colorado and Kansas, respectively, based on soil population densities, and $9 \%$ for Kansas based on root population densities. These damage models, if valid for the central Great Plains region, likely underestimate losses in this case, because of differences in timing of sample collection. Nematode populations were sampled in April and May during the tillering and boot stages for the Colorado/Kansas survey, while the yield loss models for the Pacific Northwest were based on initial (at-planting) soil population densities (for spring wheat) and root population densities at grain fill (for winter wheat). In both instances, population densities would be expected to be underestimated for our survey data relative to the Pacific Northwest model data. Soil population densities of root-lesion nematodes in spring wheat, for example, declined $87 \%$ during the first two months following planting, presumably due to nematode migration from soil into roots, while nematode densities in roots of both spring and winter wheat increased throughout the growing season (24). It is problematic, in any case, to apply damage models from the Pacific Northwest to the central Great Plains. A more valid model based on the results of several years of nematicide trials for control of $P$. neglectus and other spp. on wheat in Oklahoma (C. C. Russell, unpublished data) predicts an $\sim 1 \%$ loss in yield for each 1,000 nematodes per g dry root weight present in spring-collected samples. A similar damage relationship was observed for P. neglectus on corn in Kansas (34), suggesting that early-season root population densities of this species may provide a relatively consistent and robust estimate of yield loss for grass crops in the Great Plains. Application of this model to the survey data yields a loss estimate of $1.5 \%$ for Kansas, with $8 \%$ of wheat acreage suffering a loss of $5 \%$ or greater.

Damage relationships for $P$. thornei have been reported for winter wheat in Colorado (3) and for spring wheat in Australia, Mexico, and the Pacific Northwest $(19,20,25,36)$. Based on yield loss models for spring wheat in the Pacific Northwest, damage thresholds for $P$. thornei are significantly lower than those for $P$. neglectus $(25,26)$. Yield increases following nematicide treatment averaged $13 \%$ for a mean population of 258 P. neglectus $/ 100 \mathrm{~g}$ soil versus $98 \%$ for a mean population of $152 P$. thornei/100 g soil. Due to its low prevalence, however, this nematode appears to be of minor importance for winter wheat in the central Great Plains.

\section{CONCLUSIONS}

Stunt and root-lesion nematodes were recovered from approximately $80 \%$ of winter wheat fields in Colorado and Kansas. Nematode population densities varied significantly among fields within the same county or district, but average population densities were similar at larger geographic scales from eastern Colorado through central Kansas. Lower nematode densities were associated with crop rotation and fallow, although these effects were nematode-specific. The prevalence of $P$. neglectus and the considerable evidence of its economic impact in wheat warrant greater recognition of this nematode as an important limiting factor in wheat production in the central Great Plains. Damage relationships with greater accuracy, precision, and relevance are necessary to establish reliable yield loss estimates for root-lesion nematodes in this region.

\section{ACKNOWLEDGMENTS}

This project was partially supported by the Cooperative Agricultural Pests Survey (CAPS) of the USDA-APHIS-PPQ with Agreement Numbers 08-8453-1227-CA, 09-8453-CA, and 10-8453-1227-CA and by the Colorado Wheat Administrative Committee. We thank Bruce Bosley in Colorado and Bob Buhler and Terry Clarkson in Kansas for assistance in collection of survey samples.

\section{LITERATURE CITED}

1. Anonymous. 2012. Colorado wheat profile. Colorado Wheat, Ft. Collins, CO. http://coloradowheat.org/colorado-wheat/colorado-wheat-profile

2. Appel, J. A., De Wolf, E., Bockus, W. W., and Todd, T. 2013. Kansas cooperative preliminary wheat disease report: preliminary wheat disease loss estimates for 2013. Kansas Department of Agriculture, Manhattan, KS. http://agriculture.ks.gov/docs/default-source/pp-disease-reports2012/2013-ks-wheat-disease-loss-estimates44D2D289EE71.pdf

3. Armstrong, J. S., Peairs, F. B., Pilcher, S. D., and Russell, C. C. 1993. The effect of planting time, insecticides, and liquid fertilizer on the Russian wheat aphid (Homoptera: Aphididae) and the lesion nematode (Pratylenchus thornei) on winter wheat. J. Kans. Entomol. Soc. 66:69-73.

4. Cuarezma-Teran, J. A., and Trevathan, L. E. 1985. Effects of Pratylenchus zeae and Quinisulcius acutus alone and in combination on sorghum. J. Nematol. 17:169-174.

5. Davis, E. E., and Venette, R. C. 2004. Mini Risk Assessment - British root-knot nematode: Meloidogyne artiellia Franklin [Nematoda: Meloidogynidae]. USDA-APHIS, Beltsville, MD. http://www.aphis.usda.gov/plant health/plant pest info/pest detection/do wnloads/pra/martielliapra.pdf

6. Davis, E. E., and Venette, R. C. 2004. Mini Risk Assessment: Mediterranean cereal cyst nematode, Heterodera latipons Franklin [Nematoda: Heterodidae]. USDA-APHIS, Beltsville, MD. http://www.aphis.usda.gov/plant_health/plant_pest_info/pest_detection/do wnloads/pra/hlatiponspra.pdf.

7. Dickerson, O. J., Franz, T. J., and Lash, L. D. 1978. Influence of crop rotation on nematode populations in Kansas. (Abstr.) J. Nematol. 10:284

8. Ferris, V. R., and Bernard, R. L. 1971. Effect of soil type on population densities of nematodes in soybean rotation fields. J. Nematol. 3:123-128.

9. Georgi, L., Ferris, J. M., and Ferris, V. R. 1983. Population development of Pratylenchus hexincisus in eight corn inbreds. J. Nematol. 15:243-252.

10. Glazer, I., and Orion, D. 1983. Studies on anhydrobiosis of Pratylenchus thornei. J. Nematol. 15:333-338.

11. Jenkins, W. R. 1964. A rapid centrifugal-flotation technique for separating nematodes from the soil. Plant Dis. Rep. 48:692.

12. Kort, J. 1972. Nematode diseases of cereals of temperate climates. Pages 97-126 in: Economic Nematology. J. M. Webster, ed. Academic Press, London.

13. Langdon, K. R., Struble, F. B., and Young, H. C., Jr. 1961. Stunt of small grains, a new disease caused by the nematode Tylenchorhynchus brevidens. Plant Dis. Rep. 45:248-352.

14. Large, E. C. 1954. Growth stages in cereals: illustration of the Feekes Scale. Plant Pathol. 3:128-129.

15. Mayol, P. S. 1981. Pathogenicity of Merlinius brevidens as related to host development. Plant Dis. 65:248-250. 
16. McGawley, E. C., and Chapman, R. A. 1983. Reproduction of Criconemoides simile, Helicotylenchus pseudorobustus, and Paratylenchus projectus on soybean. J. Nematol. 15:87-91.

17. Niblack, T. L. 1992. Pratylenchus, Paratylenchus, Helicotylenchus, and other nematodes on soybean in Missouri. J. Nematol. 24:738-744.

18. Nicol, J. M. 1996. The distribution, pathogenicity, and population dynamics of Pratylenchus thornei (Sher and Allen, 1954) on wheat in South Australia. Ph.D. thesis. University of Adelaide, Australia.

19. Nicol, J. M., Davies, K. A., Hancock, T. W., and Fisher, J. M. 1999. Yield loss caused by Pratylenchus thornei on wheat in South Australia. J. Nematol. 31:367-376.

20. Nicol, J. M., and Ortiz-Monasterio, I. 2004. Effect of root lesion nematode on wheat yields and plant susceptibility in Mexico. Nematology 6:485-493.

21. Russell, C. C., and Singleton, L. L. 1989. Application of subnematicidal rates of carbofuran to winter wheat. (Abstr.). J. Nematol. 21:584.

22. Schlehuber, A. M., Pass, J., and Young, H. C., Jr. 1965. Wheat grain losses caused by nematodes. Plant Dis. Rep. 49:806-809.

23. Smiley, R. W., and Machado, S. 2009. Pratylenchus neglectus reduces yield of winter wheat in dryland cropping systems. Plant Dis. 93:263-271.

24. Smiley, R. W., Merrifield, K., Patterson, L. M., Whittaker, R. G., Gourlie, J. A., and Easley, S. A. 2004. Nematodes in dryland field crops in the semiarid Pacific Northwest USA. J. Nematol. 36:54-68.

25. Smiley, R. W., Whittaker, R. G., Gourlie, J. A., and Easley, S. A. 2005a. Pratylenchus thornei associated with reduced wheat yield in Oregon. J. Nematol. 37:45-54.

26. Smiley, R. W., Whittaker, R. G., Gourlie, J. A., and Easley, S. A. 2005b. Suppression of wheat growth and yield by Pratylenchus neglectus in the Pacific Northwest. Plant Dis. 89:958-968.

27. Smiley, R. W., Whittaker, R. G., Gourlie, J. A., and Easley, S. A. 2006. Geocenamus brevidens associated with reduced yield of no-till annual spring wheat in Oregon. Plant Dis. 90:885-890.
28. Strausbaugh, C. A., Bradley, C. A., Koehn, A. C., and Forster, R. L. 2004. Survey of root diseases of wheat and barley in southeastern Idaho. Can. J. Plant Pathol. 26:167-176.

29. Sullivan, M., Talley-Socher, S., Prokrym, D., and Hammerschmidt, R. 2007. Small grains commodity-based survey reference. Cooperative Agricultural Pest Survey (CAPS). https://caps.ceris.purdue.edu/survey/small-grains/reference/2008

30. Taylor, S. P., and Evans, M. L. 1998. Vertical and horizontal distribution of and soil sampling for root lesion nematodes (Pratylenchus neglectus and P. thornei) in South Australia. Australas. Plant Pathol. 27:90-96.

31. Thompson, J. P., Clewett, T. G., Sheedy, J. G., Reen, R. A., O'reilly, M. M., and Bell, K. L. 2010. Occurrence of root-lesion nematodes (Pratylenchus thornei and P. neglectus) and stunt nematode (Merlinius brevidens) in the northern grain region of Australia. Australas. Plant Pathol. 39:254-264.

32. Thompson, J. P., Owen, K. J., Stirling, G. R., and Bell, M. J. 2008. Rootlesion nematodes (Pratylenchus thornei and P. neglectus): A review of recent progress in managing a significant pest of grain crops in northern Australia. Austalas. Plant Pathol. 37:235-242.

33. Tobar, A., Valor, H., and Talavera, M. 1996. On the field anhydrobiotic ability of Pratylenchus thornei and Merlinius brevidens. Fund. Appl. Nematol. 19:43-46.

34. Todd, T. C., and Oakley, T. R. 1996. Seasonal dynamics and yield relationships of Pratylenchus spp. in corn roots. J. Nematol. 28:676-681.

35. U.S. Department of Agriculture Statistics Service and Kansas Department of Agriculture. 2011. Kansas Farm Facts 2011. National Agriculture Statistics Service, Topeka, KS.

36. Vanstone, V. A., Rathjen, A. J., Ware, A. H., and Wheeler, R. D. 1998. Relationship between root lesion nematodes (Pratylenchus neglectus and P. thornei) and performance of wheat varieties. Aust. J. Exp. Agric. 38:181-189.

37. Yan, G., and Smiley, R. W. 2010. Distinguishing Heterodera filipjevi and $H$. avenae using polymerase chain reaction-restriction fragment length polymorphism and cyst morphology. Phytopathology 100:216-224. 